Pye, J., Holden, H. F. \& Donald, H. B. (1956). J. gen. Microbiol. 14, 634-636

\title{
Sedimentation Behaviour and Electron Microscopic Examination of Purified Influenza Virus
}

\author{
By J. PYE, H. F. HOLDEN AND HEATHER B. DONALD \\ The Walter and Eliza Hall Institute of Medical Research, \\ Melbourne, Australia
}

Purified preparations of influenza virus were examined in the ultracentrifuge and electron microscope principally to assess the degree of purification achieved. As indicated in the main paper (Ada \& Perry, 1956) the same purification procedure was used for each batch of virus.

\section{METHODS}

Ultracentrifugation. The virus was examined in $0.85 \% \mathrm{NaCl}$ solution $(\mathrm{w} / \mathrm{v})$ at a concentration varying between 0.2 and $0.4 \%(\mathrm{w} / \mathrm{v})$. The ultracentrifuge was air-driven of the Beams-Pickels type. The speed of the rotor was 185 r.p.s. and the temperature $c .20^{\circ}$. The sedimentation was observed with a schlieren optical system having an inclined second slit. The light was of 5461 A. from a mercury arc. Viscosity measurements were carried out in an Ostwald viscometer at $25^{\circ}$.

Electron microscopy. A Siemens microscope, type UM 100, was used. The specimens to be examined were dialysed at $0^{\circ}$ against $0 \cdot 8 \%(\mathrm{w} / \mathrm{v})$ ammonium carbonate solution, sprayed on to nitrocellulose films at a pressure of $10 \mathrm{lb}$. $/ \mathrm{sq}$.in., air dried and shadowed with gold manganin.

\section{RESULTS}

Sedimentation behaviour. Most samples of standard virus showed a single peak of $S_{20}=620-800 \times 10^{-13}$. In some cases, a small amount $(<20 \%)$ of a slower component $\left(S_{20}=350-500 \times 10^{-13}\right)$ was present. The sedimentation constant was independent of concentration (within experimental error) over the range studied $(0 \cdot 2-0 \cdot 4 \%)$. Incomplete virus, PR 8 strain, whether made by two or three passages of undiluted inoculum, consistently showed decreased sedimentation constants, varying between 400 and $550 \times 10^{-13}$. Incomplete virus was usually more heterogeneous than standard virus. Relative viscosities of the virus solutions were of a similar order to those found by Lauffer $\&$ Stanley (1944), who investigated material purified by extensive differential centrifugation.

In Pl. 1, fig. 1, are shown sedimentation diagrams of purified preparations of several $\mathbf{A}$ and $\mathbf{B}$ strains and of incomplete influenza virus.

Electron microscopy. Pl. 1, figs. 2-4, show typical fields of purified preparations of standard PR8, standard LEE and incomplete PR 8 respectively. 


\section{CONCLUSIONS}

The values for the sedimentation constants for both standard and incomplete virus preparations are similar to those found by earlier workers (Lauffer \& Stanley, 1944; Gard, von Magnus, Svedmyr \& Birch-Andersen, 1952). The frequent presence of small amounts of a more slowly sedimenting component in purified preparations of standard virus has also been previously discussed and may represent small amounts of incomplete virus (Gard et al. 1952). Electron micrographs show that purified preparations of standard virus exhibit a range of particle size. It is not surprising, therefore, that the sedimentation boundaries are more spread than can be explained by diffusion. The sedimentation patterns and the electron micrographs suggest that incomplete virus has a greater range of particle size than has standard virus (see also BirchAndersen \& Svedmyr, quoted by Uhler \& Gard, 1954). Since the same conditions of purification were used for all batches of virus, the fact that the sedimentation diagrams of purified preparations of standard and incomplete virus contain no major component common to both suggests that most of the extraneous material has been eliminated. The absence of appreciable amounts of obviously non-viral material in the electron micrographs, together with the finding (to be published) that all the particles considered to be virus may be adsorbed on to red cells, provides the strongest evidence that a high degree of purity has been achieved.

The preliminary examination of purified viruses reported above has led to the initiation of more comprehensive study of the physical properties of standard and incomplete viruses. The results will be published at a later date.

\section{REFERENCES}

AdA, G. L. \& Perry, B. T. (1956). Influenza virus nucleic acid: relationship between biological characteristics of the virus particle and properties of the nucleic acid. J. gen. Microbiol. 14, 623.

Gard, S., von Magnus, P., Svedmyr, A. \& Birch-Andersen, A. (1952). Studies on the sedimentation of influenza virus. Arch. Virusforsch. 4, 591.

Lauffer, M. A. \& Stanley, W. M. (1944). Biophysical properties of preparations of PR 8 influenza virus. J. exp. Med. 80, 531.

Uhler, M. \& GARD, S. (1954). Lipid content of 'standard' and 'incomplete' influenza A virus. Nature, Lond. 173, 1041.

\section{EXPLANATION OF PLATE}

Fig. 1. Sedimentation patterns of purified influenza virus. Direction of sedimentation, right to left. Speed of rotor, 185 r.p.s. Infectivity/haemagglutinin $(I / A)$ values and approximate sedimentation times as indicated below:

(a) PR 8 (A) standard preparation, $I / A=6.3 ; 28 \mathrm{~min}$.; $S_{20}=660 S$.

(b) MEL (A) standard preparation, $I / A=6 \cdot 2 ; 34 \mathrm{~min}$.; $S_{20}=750 S$.

(c) CAM (A) standard preparation, $I / A=6 \cdot 6 ; 38 \mathrm{~min}$.; $S_{20}=620 \mathrm{~S}$.

(d) LEE (B) standard preparation, $I / A=5 \cdot 6 ; 35 \mathrm{~min}$.; $S_{20}=700 \mathrm{~S}$.

(e) MIL (B) standard preparation, $I / A=5.5 ; 34$ min.; $S_{20}=640 S$. 
(f) ROB (B) standard preparation, $I / A=6 \cdot 2 ; 27$ min.; $S_{20}=800 S$.

(g) PR 8 (A) incomplete preparation (two passages) $I / A=4.5 ; 37 \mathrm{~min}$.; $S_{20}=550 \mathrm{~S}$.

(h) PR 8 (A) incomplete preparation (two passages) $I / A=4.9 ; 44 \mathrm{~min}$; $S_{20}=510 \mathrm{~S}$.

(i) PR 8 (A) incomplete preparation (three passages) $I / A=4.4 ; 37 \mathrm{~min}$.; $S_{20}=490 \mathrm{~S}$.

(j) PR 8 (A) incomplete preparation (three passages) $I / A=3.5 ; 38 \mathrm{~min}$.; $S_{20}=400,500 S$.

Fig. 2. Electron micrograph of standard PR8. Magnification, 30,000.

Fig. 3. Electron micrograph of standard LEE. Magnification, 30,000.

Fig. 4. Electron micrograph of incomplete PR8. Magnification, 30,000.

(Received 16 November 1955) 
Journal of General Microbiology, Vol. 14, No. 3
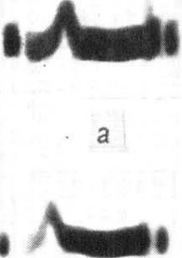

$f$

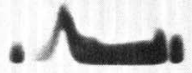

$b$

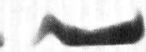

g
. 1

C

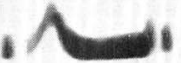

h

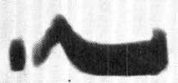

d

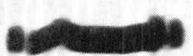

00 -
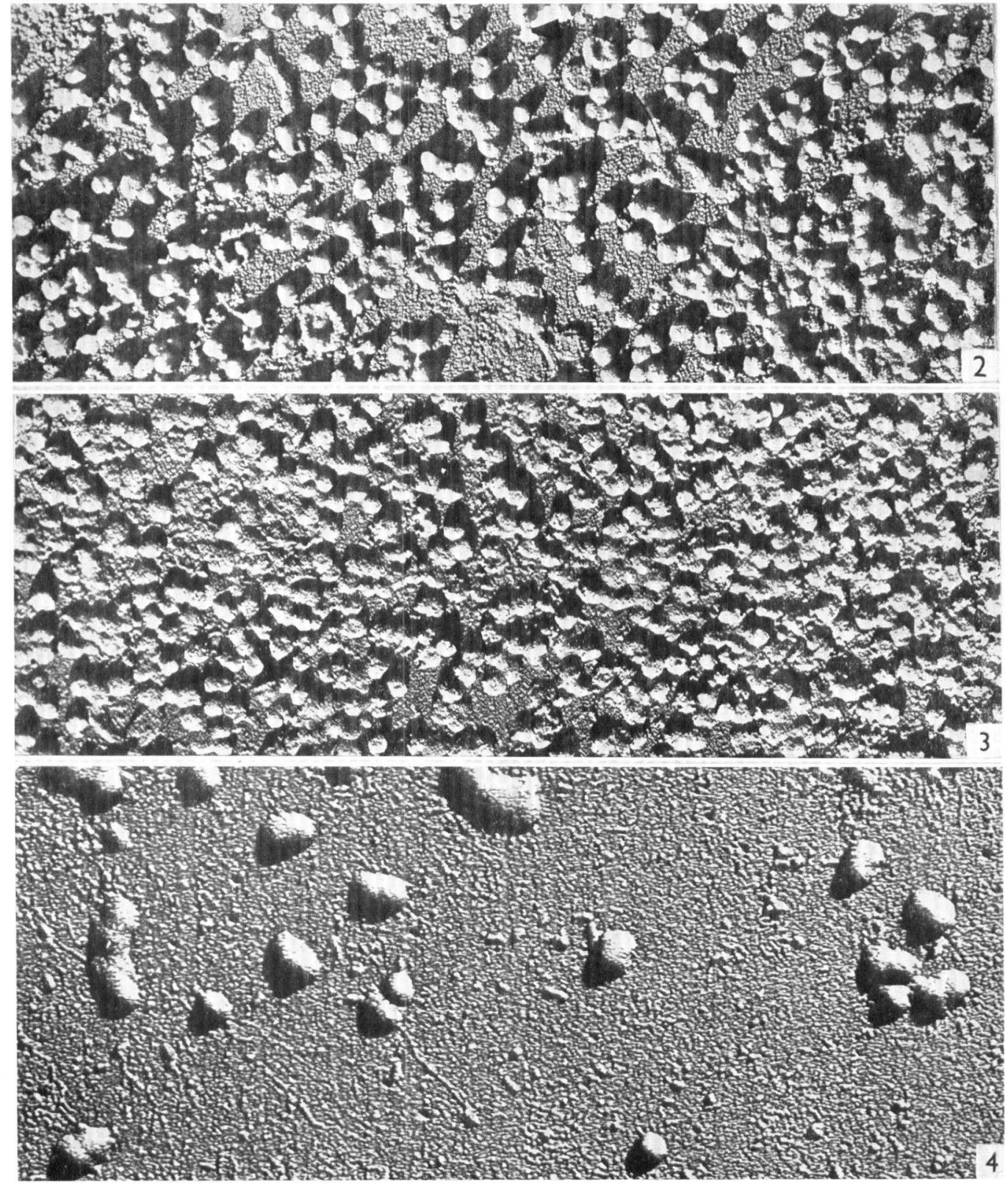

J. Pye, H. F. Holden and H. B. Donald-Examination of purified influenza virus. Plate 1 